\title{
Antibacterial Activity Analysis of Zanthoxylum Acanthopodium DC Extract on Bacteria of Bacillus Subtilis, and Salmonella Typhi
}

\author{
Nora Susanti Sihombing ${ }^{1}$, Friska Sihombing ${ }^{2}$, Tita Juwitaningsih ${ }^{3}$, Destria Roza ${ }^{4}$ and \\ Donny M Pasaribu ${ }^{5}$ \\ \{nora.susanti.s2@gmail.com ${ }^{1}$ \}
}

Chemistry Department, Faculty of Mathematics and Natural Science, State University of Medan, Jl. Willem Iskandar, Pasar V, Medan Estate, Medan, North Sumatera, Indonesia ${ }^{1,2,3,4,5}$

\begin{abstract}
Research has been conducted on the antibacterial activity analysis of Zanthoxylum acanthopodium DC extract on Bacillus subtilis, Salmonella typhi using disc diffusion method. This study aims to determine the ability of Zanthoxylum acanthopodium DC extract in inhibiting the growth of Bacillus subtillis, and Salmonella typhi. Zanthoxylum acanthopodium DC was extracted by maceration method using $96 \%$ ethanol. In this extraction process, phytochemical test was carried out to find out the secondary metabolite content in Zanthoxylum acanthopodium DC. Phytochemical test indicate Zanthoxylum acanthopodium DC contained alkaloids, tannins, saponins, and steroids. Antibacterial activity analysis were measured in three concentrations of $25 \%$, $50 \%, 75 \%$. The best antibacterial activity was observed on Salmonella typhi bacteria with $75 \%$ extract concentration which produced a clear zone diameter of $19 \mathrm{~mm}$ and 20 $\mathrm{mm}$.
\end{abstract}

Keywords: Zanthoxylum acanthopodium DC, antibacterial, disc diffusion

\section{Introduction}

Indonesian society has hundreds of years had the tradition of using plants from the surrounding environmental as traditional medicine. Spices are also used in the pharmaceutical industry (medicine) and cosmetic industry.

Food is a major human need and composed of chemical compounds which are nutrients also needed by microbes to help their growth. The presence of microbes in food come from various sources, such as raw materials, apparatus used during the processing, food storages, people involved in processing and the surrounding environment. Based on the collected data from several cases of poisoning in community, most are caused by bacteria of Bacillus subtillis, and Salmonella typhi. Bacillus subtilis is a Gram-positive bacteria form an ovalshaped endospore in the central part of cell. (Aini et al. 2013), whereas Salmonella typhiis a bacterial strain that causes typhoid fever.

Based on the research conducted by Helwina Shasti, et allin 2017 on "In Vitro Antibiotic Activity Test of (Zanthoxylum acanthopodium DC) Andaliman extract on growth of Staphylococcus aureus", the extract of andaliman (Zanthoxylum Acanthopodium DC) has the effect of antibiotics on bacterial growth of Staphylococcus aureus. In this study, it would like 
to examine of Antibacterial activity analysis of Zanthoxylum acanthopodium DC Extract On Bacteria Bacillus subtilis, and Salmonella typhi”

\section{Research Method}

The andaliman extract was obtained by maceration using ethanol. The dried andaliman fruit was made into powder and then macerated for 3 days using ethanol. The extract was concentrated by rotary evaporator to reduce the solvent. Concentrated extract was prepared into solution in different concentration $(25 \% ; 50 \%$ and $75 \%)$. The antibacterial activity was analysed using Kirby-Bauer method as a method for testing the antimicrobial susceptibility of bacteria based on the growth of inhibition zones size on a lawn culture around disks impregnated with the antimicrobial agent. The extract was also tested for its secondary metabolites content to determine the secondary metabolites presence. The secondary metabolites were analysed including the flavonoids, alkaloids, saponin, tannin, steroids and terpenoids.

\section{Results And Discussion}

Phytochemical screening and antibacterial activity are presented in the tables below.

Table 1. Secondary Metabolite Phytochemical Screening Test on Ethanol Extract

\begin{tabular}{cll}
\hline No & Phytochemical Screening & Result \\
\hline 1. & Flavonoid & - \\
2. & Saponin & + \\
3. & Tannin & + \\
4. & Steroid & + \\
5. & Alkaloid & + \\
6. & Triterpenoid & - \\
\hline
\end{tabular}

Description: $(+)=$ Exist $;(-)=$ Not exist

Table 2. Antibacterial Test Results

\begin{tabular}{cccll}
\hline \multirow{2}{*}{ No. } & \multirow{2}{*}{ Bacteria } & Concentration & \multicolumn{2}{c}{$\begin{array}{c}\text { Clear Zone } \\
\text { diameter }\end{array}$} \\
\cline { 3 - 5 } & & $\mathrm{d}_{1}$ & $\mathrm{~d}_{2}$ \\
\hline 1. & $\begin{array}{l}\text { Bacillus } \\
\text { subtilis }\end{array}$ & \multirow{2}{*}{$25 \%$} & 10 & 10 \\
& & $\mathrm{~mm}$ & $\mathrm{~mm}$ \\
& $50 \%$ & 11 & 15 \\
& & $\mathrm{~mm}$ & $\mathrm{~mm}$ \\
& & 14 & 15 \\
& & & $\mathrm{~mm}$ & $\mathrm{~mm}$ \\
\hline
\end{tabular}




\begin{tabular}{|c|c|c|c|c|}
\hline \multirow{10}{*}{2.} & \multirow{10}{*}{$\begin{array}{l}\text { Salmonella } \\
\text { typhi }\end{array}$} & Kloramfenikol & \multicolumn{2}{|l|}{$26 \mathrm{~mm}$} \\
\hline & & DMSO & \multicolumn{2}{|l|}{$9 \mathrm{~mm}$} \\
\hline & & & & 10 \\
\hline & & $25 \%$ & $7 \mathrm{~mm}$ & $\mathrm{~m}$ \\
\hline & & & & 17 \\
\hline & & $50 \%$ & $\begin{array}{l}11 \\
\mathrm{~mm}\end{array}$ & $\mathrm{~m}$ \\
\hline & & & 19 & 20 \\
\hline & & $75 \%$ & $\mathrm{~mm}$ & $\mathrm{~m}$ \\
\hline & & Kloramfenikol & $30 \mathrm{~mm}$ & \\
\hline & & DMSO & $10 \mathrm{~mm}$ & \\
\hline
\end{tabular}

In Table 1, it can be seen that andaliman phytochemical screening contains saponins, tannins, steroids and alkaloids. The antibacterial activity of andaliman extract on Bacillus subtillis (14 mm and $15 \mathrm{~mm})$ and Salmonella typhi $(19 \mathrm{~mm}$ dan $20 \mathrm{~mm})$ shows the highest activity at $75 \%$ concentration. The concentration of $25 \%$ of two bacteri was classified as medium strength while the extract with a concentration $50-75 \%$ is strong because it has inhibition zone of $11-20 \mathrm{~mm}, 5-10 \mathrm{~mm}$ of medium strength, while $<5 \mathrm{~mm}$ is categorized to be low strength.

Referring to general standard issued by David Stout it indicated microbes are susceptible to antibacterial if the plant has a size of inhibition of 10-20 $\mathrm{mm}$. It confirm that andaliman extract with concentration of 50-75\% can be used as an antibacterial.

\section{Conclusion And Recomendation}

Conclusion

1. Extract of andaliman has the best antibacterial activity withSalmonella typhiat a concentration of $75 \%$ with 19 and $20 \mathrm{~mm}$ of inhibition zone.

2. Secondary metabolite compounds found in andaliman extract which have antibacterial activity are alkaloids, steroids, tannins and saponins.

Recommendations

1. Further research is needed to determine the andaliman contents when using nonpolar, and semi-polar solvents.

2. It also necessary to determine the structure of alkaloids, saponins, tannins, steroids and tannins which function as antibacterial.

Acknowledgement. The authors thank the Indonesia Kemenristek Dikti through Unimed Research Institute for funding this research.

\section{References}

[1] Aini, F.N., S. Sukamto, D. Wahyuni, $\quad$ R.G Suhesti, dan Q. Ayyunin.: Jurnal Pelita Perkebunan, 29(1): 44-52 (2013)

[2] Puspitasari, S dan Arisanti.: Jurusan Farmasi, FMIPA, Universitas Udayana, Bali (2013)

[3] Shasti, H., Siregar, T.: . Ibnu Sina Biomedika, 1(1): 49-56 (2017) 
[4] Muzafri, A et al.: International Conference on Agriculture,Environment,and Food Security. 122: $1-7(2018)$ 